\title{
A LITERATURA DE MONTEIRO LOBATO E A ESCOLA NOVA ${ }^{1}$
}

\author{
Ana Aparecida Arguelho de Souza ${ }^{2}$
}

\begin{abstract}
RESUMO
Trata este artigo de parte de uma pesquisa sobre duas versões de uma obra de Monteiro Lobato - A Menina do Narizinho Arrebitado e Reinações de Narizinho. O objetivo é investigar em que medida as transformações ocorridas na segunda versão tem relação com o Movimento da Escola Nova e o quanto a obra contribuiu para as transformações pedagógicas preconizadas por ela. Entendendo, por uma questão de método, que toda mudança ocorrida na superestrutura se determina em última instância pelas mudanças estruturais, buscou-se apreender em um primeiro momento no cenário histórico no Brasil, as transformações da literatura enquanto fenômeno superestrutural, no bojo das quais atua Monteiro Lobato. A seguir procurou-se aprender nos fundamentos da Escola Nova os elementos aproximativos à literatura de Lobato que pudessem ter influenciado em sua escrita e a medida dessa influência. A pesquisa conclui que houve sim uma relação com a Escola Nova, mas que as injunções que modificaram a obra são mais amplas do que uma intencionalidade direcionada para atender especificamente os ditames desse movimento pedagógico.
\end{abstract}

Palavras-chave: Literatura; Educação; Monteiro Lobato; Escola Nova.

\section{MONTEIRO LOBATO'S LITERATURE AND THE NEW SCHOOL}

\begin{abstract}
This article is part of a research on two versions of a work by Monteiro Lobato - A Menina do Narizinho Arrebitado and Reinações de Narizinho. The focus is to investigate to what extent the changes occurred in the first version has a connection with the Movement of the New School and how much the work contributed to the pedagogical transformations advocated by it. Understanding, as a matter of method, that any changes occurred in the superstructure is ultimately determined by the structural changes, it was sought to apprehend at a first moment in the historical scenario in Brazil, the transformations of literature as a superstructural phenomenon, in the bulge of which it acts Monteiro Lobato. Next, it was pursued to learn, based in the foundations of the New School, the elements roughly to the literature of Lobato that could have been influenced in its writing and the measurement of this influence. The research concludes that indeed there was a relationship with the New School, but that the injunctions that modified the work are broader than a directed intentionality to specifically meet the dictates of this pedagogical movement.
\end{abstract}

Keywords: Literature; Education; Monteiro Lobato; New School. 


\title{
Introdução
}

\begin{abstract}
Um dos grandes "achados" de Lobato, tal o de seus antecessores, $L$. Carrol e Collodi, foi mostrar o maravilhoso como possivel de ser vivido por qualquer um. Misturando o imaginário com o cotidiano real, mostra como possíveis, aventuras que normalmente só podiam existir no mundo da Fantasia (COELHO, 1985, p. 96).
\end{abstract}

Este texto é parte de uma pesquisa que investiga a relação entre a literatura infantil de Monteiro Lobato e o movimento da Escola Nova, ocorrido no Brasil em torno dos anos de 1930, especialmente, e que, decisivamente, assinalou novos rumos para a educação brasileira. O ideário da Escola Nova vem no bojo de ideias de renovação mais universal, provocada, em última instância pelas crises do capital concorrencial, no último quartel do século XIX e que vai resultar na recomposição do capitalismo em sua forma monopólica e em inevitáveis transformações culturais.

A pesquisa tem requerido que se proceda a um fino recorte na copiosa obra e na vida de Monteiro Lobato (1882 - 1948), intelectual paulista cuja trajetória fecunda reuniu em si o trabalho de jornalista, editor, artista plástico, crítico literário, mas, acima de tudo, escritor e, como tal, constituiu, com sua linguagem e narrativa inaugurais, um divisor de águas na moderna literatura brasileira, de modo especial, na literatura infantil. É, porém, o Lobato educador, que aqui mereceu mais uma investigação, de modo a responder a essas questões:

Em que medida contribuiu com a pedagogia nova que se inaugurava como uma das mais fortes expressões dos confrontos entre a velha e conservadora oligarquia do café a nascente burguesia industrial? Em que medida ocorreu o alinhamento desse intelectual que mereceu a alcunha de furacão (AZEVEDO; CAMARGOS; SACCHETTA, 2001) com os intelectuais liberais que atuaram no campo da educação brasileira propondo uma educação nova?

Há uma tendência da crítica em associar Lobato com a Escola Nova, supondo que o doutrinário escolanovista houvera influenciado o escritor, provocando modificações em sua literatura. Isso de fato ocorre? O quanto a literatura de Lobato foi influenciada pela nova pedagogia que ganhava fôlego em um Brasil de mudanças econômicas e políticas, ou o quanto influenciou e mudou os rumos da linguagem e da literatura infantil nas escolas brasileiras? Espera-se, ao final, ter-se respondido a essas questões.

As premissas desta investigação apontam para um Lobato cujas intenções e práticas literárias, se por um lado encontram, sim, eco no ideário escolanovista, por outro, assinalam uma ânsia de mudança que o marcou desde a infância e que tem uma medida maior, manifestada já no início do século XX, ganhando força no movimento modernista da literatura e das artes que culminou na Semana de Arte Moderna. Movimento que posteriormente teve desdobramentos significativos, modificando as bases da cultura brasileira indelevelmente. Endossa e acirra as aspirações de Lobato toda a dinâmica da sociedade e da educação brasileira desde os primórdios da República, mas em um plano pessoal e mais próximo, o desejo de uma literatura menos imbecilizada para a educação de seus filhos e a consciência de um Brasil precário e ainda colonial. Alie-se a isso, o seu encanto/desencanto com a "roça", de onde extrai seu primeiro e significativo personagem brasileiro, que atesta sua preocupação com a situação do país: o Jeca Tatu. Lobato, que recebera como herança do avô uma fazenda de café, vê-se às voltas com dificuldades de várias ordens - terras já improdutivas, intempéries climáticas e políticas econômicas catastróficas. Encontra na cidade de São Paulo, onde se formara em Direito e já praticava o jornalismo, uma forma de sobrevivência e de reprodução do capital que lhe caíra nas mãos 
com a morte do avô, com a compra da editora Monteiro Lobato e Cia em fins de 1918. A partir da falência da mesma, dedica-se com mais afinco à produção literária. O envolvimento com os ideais da Escola Nova ocorre por volta de 1928/29, quando, então, passa a ter contato com os escolanovistas.

No Brasil, as mudanças estruturais ocorrem na transição de um país de economia rural para a formação de uma indústria que, mesmo incipiente, exige mudanças de ordem superestrutural. Os dois grandes eventos que atestam esse desejo de mudança, a Semana de Arte Moderna e a Escola Nova, encontram em Lobato um intelectual afinado com o seu tempo, que marca presença nos dois movimentos, embora de um lugar que atesta seu desejo permanente de garantir sua individualidade e liberdade. Lobato não é homem de um movimento, de um partido político, de compartilhamentos sociais, enfim. Quis ser único e teve fôlego para tanto. Se passou pelos dois movimentos e com eles contribuiu, o fez com muita liberdade e autonomia.

\section{O objeto e as fontes}

Talvez por não ser um educador por formação, mas um escritor, a presença de Lobato na Escola Nova só pode ser apreendida por suas obras voltadas para a infância e pelas cartas que troca com o amigo e companheiro de sonhos, Anísio Teixeira. Considerando, então, que o eixo definidor da pesquisa é a relação da literatura de Lobato com a Escola Nova foi necessário proceder a um recorte na sua vasta obra, em torno daquilo que mais significativamente consideramos consoante com os fundamentos escolanovistas, elegendo como objeto a ruptura operada por Lobato com a linguagem empolada, hermética e carregada de moralidades presentes em obras da literatura brasileira que circulavam pelas escolas, bem como a aproximação da literatura com o universo infantil por meio do necessário abrasileiramento não só da linguagem, mas de todos os elementos que compunham o cenário estético onde iriam se desenvolver as tramas narrativas em suas obras. Pelas mãos de Lobato a literatura veio ao encontro de atender as expectativas e interesses infantis, como preconizava o escolanovismo. A aproximação de Lobato com os escolanovistas e suas aspirações pedagógicas acabou por criar o elo necessário entre as crianças e a literatura.

Nessa direção, a pesquisa envolve duas áreas do conhecimento: a área de letras, quando investiga o teor linguístico e narrativo de uma literatura infantil inaugural, tanto no abrasileiramento e popularização da linguagem, com que Lobato alterou formas literárias e temáticas e ressignificou as mitologias e fabulários universais, rumo à valorização de uma literatura e uma cultura genuinamente brasileiras; e a área da educação fazendo convergir a investigação para o ideário da Escola Nova e das mudanças na organização do trabalho didático, entrevistos nas propostas dos seus participantes e investigando em que medida se dá a relação de Lobato com estes, bem como sua contribuição com o movimento.

A obra de Lobato em conjunto e individualmente foi abordada pela crítica em suas diversas possibilidades e nuances. Para fins da pesquisa, a partir da observação dos ditames da Escola Nova, o critério de seleção de obras para uma revisão de literatura que permitisse inventariar o objeto foi o de eleger pesquisas que abordam as possibilidades de aproximação da literatura de Lobato com a nova educação que se inaugurava no Brasil, em suas circunstâncias, relações e intenções. Foram encontradas várias fontes que relacionam a produção de Lobato com a educação, mas não especificamente com a Escola Nova. Em termos de uma literatura contemporânea que fizesse essa relação encontramos a tese de Bertolucci, que menciona de maneira episódica o Manifesto dos Pioneiros, indicando como 
fonte a obra de Nelly Novaes Coelho, Panorama histórico da literatura infantil/juvenil. (COELHO, s/d, p. 227 apud BERTOLUCCI, 2005, p. 93)

Para esse inventário, tomamos não só a produção contemporânea, mas algumas produzidas no calor da hora e que, por isso mesmo, extremamente reveladoras.

Para fins deste artigo elegemos duas versões da obra Reinações de Narizinho, com o fim de examinar, comparativamente, as mudanças entre uma e outra que, provavelmente, o autor realizou com o fim de aproximar a linguagem da obra do universo infantil. Abordamos comparativamente alguns aspectos dessa mudança e também expusemos alguns textos que circulavam nas escolas brasileiras anteriormente à obra de Lobato, para caracterizar bem a mudança ocorrida, em termos da literatura.

A versão inaugural da obra aqui estudada foi lançada em $1^{a}$ edição, a 21 de dezembro de 1920 pela "Revista do Brasil" Monteiro Lobato e \& - São Paulo, com o título de A menina do Narizinho Arrebitado - livro de figuras por Monteiro Lobato com desenhos de Voltolino. Posteriormente, em 1921, Lobato lança uma $2^{a}$ edição com o título Narizinho Arrebitado, pela mesma editora, como segundo livro de leitura, para uso nas escolas. A partir daí, várias histórias curtas teriam sido reunidas em uma só obra, com o nome Reinações de Narizinho e publicada em 1931, justamente no apogeu do movimento da Escola Nova no Brasil. Essa última é a versão que resiste até os dias atuais, na qual Monteiro Lobato narra as inúmeras aventuras das personagens, no Sítio do Pica-Pau Amarelo. De modo que qualquer edição, a partir daí, pode servir de parâmetro para comparação com a versão inicial e, nesse sentido, a segunda escolha recaiu sobre uma versão integral da obra, cedida pela família de Lobato e pela Editora Brasiliense ao Círculo do Livro S/A, constante de uma coleção das obras infantis do autor, editada na década de 80.

Anteriormente à criação dessa obra inaugural, o autor já houvera feito incursões pela literatura. Segundo Barbosa (1982, p. 47) no ensaio, Monteiro Lobato e o direito de sonhar, que acompanha o fac símile da obra A menina do Narizinho Arrebitado, o autor, com a ideia de escrever um romance para crianças, pensava em transformar o mito popular de Pedro Malasartes numa réplica nacional do Barão de Munchausen e abrasileirar a fórmula das fábulas de Esopo e La Fontaine, projeto que, em parte, acabou concretizando.

Também idealizou sobrelevar o mito mais popular do Brasil, o Saci Pererê, como alternativa aos mitos estrangeiros cultivados no Brasil à época. Promoveu uma pesquisa de amplitude nacional sobre essa figura mítica, que redundou na obra $O$ Saci Pererê: resultado de um inquérito lançada em 1918. Em todos esses projetos está muito visível a marca mais acentuada do escritor: seu veio nacionalista.

\section{A primeira versão da obra}

É Lobato que conta como surge a primeira versão da obra. Durante uma partida de xadrez com um amigo, ouve desse a história de um peixinho que morrera afogado porque desaprendera de nadar durante uma estada em terra firme. De volta ao rio se afogara. $\mathrm{O}$ autor disse que perdeu a partida porque o peixinho não havia mais parado de nadar em sua imaginação. Surge a ideia de dar maior desenvolvimento à história, incorporando o cenário da sua meninice pois "acudiram-lhe cenas da roça". Nasce assim, em 1920, a primeira versão que recebe o título de A Menina do Narizinho Arrebitado. Em um Caderno-Documento, entregue por Lobato a uma amiga de nome Marina, ele menciona a obra como sendo "o olho d'água da minha literatura infantil" (AZEVEDO apud BIGNOTO, 1999).

A obra teve uma tiragem de 50.000 a 60.000 exemplares. Essa diferença e suas circunstâncias são narradas por Barbosa (1982, p. 51). Dessa tiragem, que se esgota em 8 ou 9 meses, Lobato reserva 500 exemplares para distribuição gratuita nos grupos escolares 
públicos de São Paulo. Conta Edgar Cavalheiro (apud BARBOSA, 1982, p. 51), biógrafo de Lobato, que Washington Luis, presidente de São Paulo na ocasião, percorrendo as escolas, notou em todas, a presença de um livrinho surrado e sujinho. Por essas características julgou ser o preferido das crianças e fez a encomenda de 30.000 exemplares.

Qual a causa desse sucesso? O que motivou as crianças a consumirem vorazmente essa literatura dentro das escolas? Teria o interesse das crianças suscitado em Lobato a preocupação de se dedicar à literatura infantil, formulando uma literatura inovadora, com linguagem e personagens à brasileira que, dentro do que preconizava a Escola Nova, poderia contribuir para despertar no aluno o interesse pela leitura e literatura? Entender melhor essa literatura e suas motivações é a questão que orienta este artigo.

\section{As circunstâncias históricas e a situação da literatura no Brasil, no entre séculos}

Dentre os fatores que, para além da Escola Nova no Brasil, contribuíram para que a obra aqui analisada tomasse os rumos que tomou, registra-se um de ordem mais universal acerca dos rumos da própria literatura desde o século XVII; e outro, que circunscreve o espírito colonialista que pairava nas nossas escolas ainda no século XX.

Na obra Literatura na escola... procurou-se demonstrar o movimento da burguesia em criar e estimular um novo mercado, o da literatura infantil. Observou-se que, por toda Europa, ocorreu um intenso movimento de recolher narrativas do ideário folclórico e popular da Idade Antiga, mas especialmente, as histórias picantes da Idade Média, narradas entre lenhadores nas noites de inverno, em torno das fogueiras, para reescrevê-las, escoimando-as de suas luxúrias e adaptando-as a uma linguagem infantil e a ilustrações apropriadas à despertar o gosto da literatura entre as crianças. Pensamos que este movimento do mercado é o determinante de última instância que está na origem inclusive do pensamento sobre uma nova educação, que vem medrando desde o século XVII na Europa, a partir da invenção da imprensa e da criação de uma indústria de livros.

É importante frisar que todo esse movimento livreiro destina-se a uma classe específica, a burguesia europeia florescente e abastada. As histórias de civilizações passadas sofriam um processo de adoçamento para tornar-se palatável a um novo público emergente, as crianças oriundas da classe burguesa, recebendo o nome de literatura infantil.

Nesse tipo de literatura infantil moderna, além dos componentes estéticos estruturantes dos contos em geral - personagens, lugar, tempo, linguagem, organização e foco narrativo - a disposição do texto no papel, as escolhas gráficas, a ilustração, tudo disputava espaço na busca das opções valorativas, éticas e pedagógicas eleitas pelos autores, adaptadores ou tradutores, para que a narrativa alterasse os horizontes de expectativas dos pequenos leitores e sedimentasse os valores formativos eleitos pela burguesia para a formação de seus quadros (SOUZA, 2010, p. 763).

Às crianças que compunham o conjunto dos filhos da grande massa da classe operária, ao longo de aproximadamente três séculos, XVII a XIX, se destinava um tipo de literatura que incluía diversos contos bíblicos e morais, bem como espécies degradadas da grande literatura universal - as chamadas "traduções livres". Tratavam-se de versões de obras consagradas nas quais a linguagem e o enredo eram aviltados em nome da liberdade e da adaptação a diferentes realidades. Salem (1970, p. 35) aponta o caso de Robinson de Paris, tradução livre de Robinson Crusoé, escrita em 1840, por Eugénie Foa, "história de um menino que se encontra sozinho em Paris, sem dinheiro e sem conhecer ninguém na 
cidade". Eram traduções que intentavam transmitir às crianças do povo a moralidade necessária ao movimento de expansão e solidificação da nova sociedade. Com o passar do tempo tais traduções iam se deteriorando. Zilberman assim expressou o processo de decadência de histórias adaptadas: "Adaptações de adaptações, as histórias começaram a falar de um mundo sem qualquer vínculo com a possível experiência do leitor". (ZILBERMAN, 2003 apud SOUZA, 2012, p. 764)

Ademais, sendo o ideário medieval desenvolvido no cenário europeu, as histórias contendo bruxas, fadas, palácios e carruagem mostravam-se pouco adequadas às crianças dos trópicos brasileiros, na visão dos educadores comprometidos com a afirmação de uma identidade nacional.

Muito embora o Brasil compusesse uma mesma totalidade com a Europa, de onde extraía o grosso das ideias, era marcado por suas idiossincrasias. Neste rincão, no século XIX, a precarização das escolas, da leitura e do livro atingia até mesmo as camadas sociais mais abastadas, em condições de receber apenas a literatura possível, significa dizer, a literatura importada da Europa, especialmente, de Portugal. Um incipiente esforço de produção de uma literatura nacional para crianças vai ser percebido com os ventos da república, embora desde a primeira metade do século XIX, pelo registro dos programas curriculares do Colégio Pedro II (VECHIA; LORENZ, 1998) já se pudesse notar a introdução de uma literatura mais expressiva para a adolescência e a juventude. É o Pedro II a mais importante expressão da escola brasileira no século XIX. Por suas salas passaram os mais significativos quadros da intelectualidade brasileira, como Silvio Romero que, pelos seus escritos, deixou registrada não só a qualidade da reflexão sociológica e literária de seu tempo, como também as mudanças que os desdobramentos da proclamação da república instauraram no cenário das letras brasileiras. Com sua reflexão acerca da raça brasileira, na obra Compêndio de História da Literatura Brasileira, a literatura é deslocada de uma historiografia portuguesa e colocada no coração do Brasil. Obra que sendo adotada no Colégio Pedro II, será o ponto de partida para o estudo da literatura brasileira em bases nacionalistas.

No âmbito das escolas fundamentais, entretanto, até dobrar os sinos do século XIX, a ausência de livros de literatura ficou patenteada por inúmeros escritores brasileiros que, em suas obras, relataram suas experiências com a pedagogia e os materiais didáticos da época. Nelas não se incluem senão uma parca literatura transplantada da Europa e utilizada como pretexto ao ensino da gramática.

No correr do século XIX para o XX, especialmente com a passagem do Império à República, essa literatura estrangeira, com ênfase à portuguesa, vai cedendo lugar a outra, de cunho patriótico, que revela um Brasil em busca de identidade nacional, de seus valores genuínos e de sua afirmação como país livre. Com uma linguagem ufanista e grandiloquente, vai nascendo uma literatura eivada das moralidades burguesas em terras brasileiras, de valorização da pátria, do trabalho, da família e da escola, pilares máximos da sociedade burguesa, como pode ser entrevisto em diversos autores brasileiros, como por exemplo, em Olavo Bilac (1904, p. 114), parnasiano ufanista e patriota, nestes versos enfadonhos porque carregados de moralidade, extraídos da obra Poesias Infantis:

A Pátria

Ama, com fé e orgulho, a terra em que nasceste!

Criança! não verás nenhum país como este! 
Olha que céu! que mar! que rios! que floresta!

A Natureza, aqui, perpetuamente em festa,

É um seio de mãe a transbordar carinhos.

Vê que vida há no chão! vê que vida há nos ninhos,

Que se balançam no ar, entre os ramos inquietos!

Vê que luz, que calor, que multidão de insetos!

Vê que grande extensão de matas, onde impera

Fecunda e luminosa, a eterna primavera!

Boa terra! jamais negou a quem trabalha

O pão que mata a fome, o teto que agasalha...

Quem com seu suor a fecunda e umedece,

vê pago o seu esforço, e é feliz, e enriquece!

Criança! não verás país nenhum como este:

Imita na grandeza a terra em que nasceste!

(OLAVO BILAC, 1904, p. 114).

Também em Rolim $^{3}$ (1897, p. 15) está presente o ideário nacionalista:

\section{PELA PÁTRIA!}

EI-LA! Como é bonita!

- arma de general -

Vê-la somente, excita

Bravura sem igual

E eu hei de abrir fileiras,

E glórias mil e mil

Colher sob as bandeiras,

Ovantes, do Brasil!

Aqui, a apologia ao trabalho e à poupança, valores burgueses, por excelência:

O TRABALHO.

VOU cuidar das minhas plantas;

Levo a enxada e o regador.

Que alegria nas flores! Quantas, quantas

Nasceram a este dia criador!

É preciso visitá-las;

Dar-lhes logo as boas vindas.

Meu Deus! E todas se expandindo em galas!

Dálias e rosas nunca vi tão lindas!

Loiro par de borboletas

Sinto esvoaçar sobre mim.

Bem sei: anda à procura das violetas

E não sabe os recantos do jardim.

Que tolinhas! O perfume

Não lhes ensina o caminho?

O perfume da flor é como o lume:

Atrai a gente ao desejado ninho.

Bom. Lá seguem meu conselho:

Adiantam-se leves no ar...

Até logo, até logo!... E eu me aparelho

Para em calma e sossego trabalhar. 
O trabalho revigora;

Eu gozo, quando moirejo;

A fina aragem, que os vergéis explora,

Tem a doçura mágica de um beijo.

E nem o sol me faz medo:

Suporto-o fresca e louçã.

Apenas, se em labor demais me excedo,

Levo no rosto as tintas da romã.

E sinto um gozo profundo,

- Que é a minha esplêndida messe,

Ao saber que sou útil neste mundo,

E alguém da minha proteção carece.

(ROLIM, 1897, p. 21).

Nada mais ilustrativo, todavia, do ufanismo grandiloquente e do distanciamento entre a linguagem e a criança, que o Descobrimento do Brasil, em Coelho Neto, na obra A Pátria Brasileira, em parceria com Olavo Bilac. Um exemplo de linguagem apologética, empolada e distante da realidade brasileira, para contar a história do Brasil:

\section{DESCOBRIMENTO DO BRASIL}

[...] Estabelecido o riquíssimo comércio das especiarias, a fim de assegurálo a Portugal, partiu da foz do Tejo, a 9 de Março de 1500, uma esquadra de 13 embarcações, alguma das quais armadas a expensas de particulares, todas, porém sujeitas ao mando do capitão mor Pedro Álvares Cabral, de ilustre família, mas ainda sem feitos que lhe desse lustre ao nome.

Pelas instruções escritas que recebeu, devia afastar-se, tanto quanto pudesse, da África, na altura da Guiné, para evitar as calmarias. [...]

A esquadra aproximou-se da costa no dia seguinte, indo um batel à terra com gente, sendo porém possível comunicação alguma por não entenderem os intérpretes a língua dos naturais, reduzindo-se todo o tratado a algumas dádivas e trocas de parte a parte.

Decidindo-se a explorar a terra que se alongava para o Norte, Cabral, no dia seguinte, velejou em demanda de uma angra onde ancorasse se abastecesse de água, encontrando, dez léguas ao Norte, tão propícia enseada que lhe deu o nome significativo de Porto Seguro.

E assim, por um acidente feliz, foi encontrado sobre os mares o continente verde de nossa pátria.

O solo fertilíssimo, forrado de ervas balsâmicas que despontam em flores, esconde no seio tesouros incontáveis que só esperam o esforço do homem para vir ao lume da terra.

Rios caudalosos cruzam-no fertilizando-o, e são outras tantas estradas por onde vão, de um extremo a outro do país, as barcas de comunicação. Cachoeiras precipitam-se de alturas prodigiosas com estupendo fragor. [...]

Freme o jaguar nas brenhas, o tapir assobia, as grandes cobras silvam enroscadas nos troncos ou de rastro pelas ervas; nos campos, os veadinhos meigos saltam e iraras correm. à beira dos rios, abundantes em pescado, arrastam-se répteis; e garças brancas pousam contemplativas, e tantas, que de longe parece à gente que um lençol se estende à beira das águas. [...]

Para completa prosperidade de uma terra tão prodigamente aquinhoada, basta que ao seu viço correspondam o esforço e o amor do homem; e, agora que, consciente da grandeza da pátria que possue, o 
brasileiro se lhe dedica com todo o interesse, o Mundo volta os olhos pasmados para esta região de magnificências, invejando-a, e já a procuram os desfavorecidos para viver, acolhidos à sombra das suas árvores, em comunhão pacífica e laboriosa, gozando a paz e preparando a abastança (OLAVO BILAC, 1940, s.p.).

O que assinala uma unidade nessas linguagens é o distanciamento de um padrão linguístico que materializasse, verdadeiramente, a "alma brasileira" e o Brasil, país com peculiaridades e cultura muito diferentes dos países europeus, com problemas de ordem política, de saneamento, de precarização da saúde e da cultura, problemas que estiveram presentes nas preocupações dos intelectuais da nova educação e em Monteiro Lobato, especialmente, em sua obra destinada ao público adulto. Na literatura anterior a Lobato, é visível o artificialismo da linguagem e dos conceitos, quando os textos praticamente buscam "vender" a ideia de que o Brasil é o paraíso. É preciso lembrar que, ao tempo de Coelho e Bilac, o modo colonialista de desenvolvimento, ao longo dos séculos, nem de longe deixava entrever uma natureza idílica, já alterada agressivamente pelas mãos da Coroa Portuguesa, mesmo com a elevação do país a reino unido ou império.

Também vigoram nas escolas anteriores a Lobato, as fábulas importadas da Grécia e da França, como é o caso das fábulas de La Fontaine ou Os doze trabalhos de Hércules, o que levou Lobato a segredar ao seu amigo Godofredo Rangel: "Ando com várias ideias. Uma: vestir à nacional as velhas fábulas de Esopo e La Fontaine, tudo em prosa e mexendo nas moralidades. Coisa para crianças" (LOBATO, 1972, p. 246 apud MARTHA, 1999, p. 72).

No original, as fábulas são escritas em versos e com linguagem rebuscada, levando o autor a expressar assim seu pensamento sobre essas: "As fábulas em português que conheço, em geral traduções de La Fontaine, são pequenas moitas de amora no mato espinhentas e impenetráveis". (LOBATO, 1972, p. 246 apud MARTHA, 1999, s.p.)

Confirme-se a afirmação anterior, nesta estrofe da fábula $O$ lobo e o cão, traduzida pelo Barão de Paranapiacaba, antes que Lobato lhe pusesse as tais novas roupagens (LA FONTAINE, s.d., p. 30):

Certo lobo que estava na espinha,

(Pois os cães bem velavam no gado)

Dá com um dogue possante e formoso,

Limpo e sécio, a luzir de anafado.

$\mathrm{Na}$ adaptação em prosa, um trecho da mesma fábula, com a nova roupagem lobatiana:

Um lobo muito magro e faminto, todo pele e ossos, pôs-se um dia a filosofar sobre as tristezas da vida. E nisso estava quando lhe surge pela frente um cão - mas um cão e tanto, gordo, forte, de pelo fino e lustroso (LOBATO, 2002, p. 29).

Por esse pequeno exemplo pode-se avaliar a preocupação de Lobato com a linguagem, o que torna seu trabalho mais abrangente, envolvendo adaptações de obras clássicas da literatura universal, além da criação de uma literatura genuinamente brasileira. É importante registrar que, paulatinamente, Lobato muda o curso da sua literatura, dedicando-se a escrever para as crianças e difundindo suas ideias sobre o Brasil, em obras como $O$ poço da Visconde, por exemplo, na qual, metaforicamente, alerta o país e formula rumos para a superação da crise do petróleo. 
Lobato é um nacionalista, mas abomina as tintas literárias que não revelam a verdadeira face do país. Toda sua obra respira o desejo de contribuir para que o país avance no processo civilizatório, naturalmente dentro da perspectiva liberal. $\mathrm{O}$ nacionalismo é o carro chefe de décadas de efervescência cultural. No entanto, segundo Lajolo e Zilberman (1985, p. 56), se o autor é fiel à sua geração, é também dissidente do nacionalismo eufórico que assola entusiasticamente o país e, nesse sentido, sua voz encontra eco no Brasil de Macunaíma e demais obras de Mário de Andrade. Ambas literaturas falam de um país infestado de saúvas, doenças e misérias. Encontra-se no artigo de Tambara e Arriada (2009, p. 287) uma análise ilustrativa dessa diferença entre o nacionalismo eufórico e o nacionalismo de Lobato. Ao comentar a concepção educacional de Simão Lopes de Almeida, os autores mencionam que ele tinha sempre em mente a crença na importância dos livros de leitura e que os mesmos deveriam ter toda uma compleição que privilegiasse a educação cívica, os faustos nacionais, a brasilidade, as características regionais. Essa reivindicação de um nacionalismo atrelado à educação cívica e os faustos nacionais é o que povoa as obras infantis no rumo da literatura falsamente nacionalista porque ufanista, artificial e apologética. Bem longe disso se coloca o nacionalismo dos modernistas críticos e conscientes do problemas da nação como Mario de Andrade e o próprio Lobato. Um nacionalismo fecundo e realista, que encara os problemas do Brasil de frente, denuncia suas mazelas por meio da literatura e luta para resolvê-los.

Quando em 1921 Lobato lança a primeira edição do livro infantil A Menina do Narizinho Arrebitado, segundo livro de leitura para uso escolar, circulava nas escolas de São Paulo, o Primeiro livro de leitura morais e instrutivas de João Köpke, considerado por Lobato como "insulso e de não facil compreensão por cérebros ainda tenros (sic)" (LOBATO, 1956, p. 193 apud SANTANA, 2011 p. 57). É contra esse tipo de linguagem que Monteiro Lobato vai se insurgir, contra essa europeização das letras e da cultura que impedia a criação de um ideal estético nacional genuíno e verdadeiro. Lobato abomina o que chama de imitativismo que, segundo ele, impregna a mentalidade brasileira, "contente em reproduzir, em todos os níveis, o modelo europeu, do qual se torna cópia fajuta..." (LOBATO apud AZEVEDO et al., 1998, p. 64).

É neste cenário brasileiro, com a educação nesse patamar que vão germinar as ideias de uma nova educação e de uma nova literatura, na qual Lobato tem um papel decisivo no âmbito da leitura e da literatura. São dessas determinações que nascem concomitante e enlaçadas as ideias da Escola Nova e a literatura infantil de Lobato que marcará indelevelmente essa transição e irá se perpetuar como a melhor literatura infantil brasileira. O nosso clássico.

\section{A literatura de Lobato e os princípios da Escola Nova}

Entender a literatura de Monteiro Lobato dentro de uma perspectiva que considere a interferência de determinações mais amplas na singularidade do objeto, é entendê-lo, manifestamente, como parte de um complexo concreto que se desenvolve no Brasil, como expressão do movimento de internacionalização do capital. O cenário de transformação de um Brasil agrário, comandado por uma classe rural oligárquica, para outro, em que uma burguesia urbana, toma para si, paulatinamente, essa tarefa, implica considerar o processo de uma incipiente industrialização que permite a caminhada do país rumo à modernização, e que busca fortalecer o sentimento de nação, no sentido de se alinhar às inovações do capitalismo internacional no plano da materialidade e das ideias. 
Tal processo tem início, ainda no século XIX, com o movimento abolicionista - que nada mais foi do que uma necessidade do capital internacional - acionado pelos braços brasileiros dos cafeicultores, os maiores interessados em uma nova concepção de trabalho e de circulação de mercadorias que provoca o êxodo rural e a ampliação das camadas urbanas de população. A culminância desse movimento se dá na década de 30, quando passa a exigir, no plano brasileiro, a mesma universalização do ensino que, já no século XIX, ocorrera na Europa pelo mesmo processo de internacionalização do capital e ampliação do mercado em plano mundial. E mais, passa a exigir uma nova educação que seja capaz de atrair e manter na escola o tipo de aluno de que o capitalismo precisa para a formação dos seus quadros. Getúlio Vargas é a figura de proa, que vai capitanear esse movimento, com não menor rigor que nos polos nazista e fascista, nos quais o capitalismo atuou, feroz e vigorosamente, para a formação de novos quadros com vistas à extração da mais valia necessária a elevação do capitalismo a novos patamares de acumulação, concentração e centralização de capitais (SOUZA, 2012, p. 768).

Dentro desse aparentemente auspicioso cenário do ponto de vista do estado liberal alinhado à ideia progresso mundial, constrói-se um doutrinário de nação prospectiva e preparada para comandar seus destinos. Isso naturalmente exige um novo modelo educacional capaz de construir cidadãos autônomos, com ideias próprias. A esse movimento educacional, que representou a confluência das forças liberais brasileiras com influências externas da democracia americana, chamou-se "Escola Nova" e foi comandado pelos melhores quadros da intelectualidade liberal burguesa. Constava entre eles, em destaque, Lourenço Filho, Anísio Teixeira e Fernando de Azevedo, que trabalharam arduamente pelo êxito de uma educação consoante com os novos ventos da república. Como seria a escola dentro desse ideário? Diz Fernando Azevedo, na obra A educação e seus problemas: ... "um centro de vida social", uma múltipla atividade de colmeia a que cada um leve como abelhas a safra diária, de seus gostos de seus interesses, de sua iniciativa tão original quanto possível..." (AZEVEDO, 1948, p. 193).

No Brasil, os princípios e fundamentos dessa nova educação, que iniciara em vários países na Europa, assentaram-se, especialmente, nas ideias de John Dewey, fundador da Escola Filosófica do Pragmatismo nos Estados Unidos. Dewey, no conjunto de várias obras, formula uma concepção de educação sustentada em novas bases, antagônicas às da chamada escola tradicional. Na base do pensamento de Dewey está a democracia americana e é lá, nos Estados Unidos, e nesse pensamento pedagógico, pautado no exemplo concreto e fascinante da experiência americana, que Anísio Teixeira vai buscar inspiração. Segundo Nunes (1986, p. 6), esses elementos "transformaram nele a fé religiosa tradicional, em fé nas possibilidades do Homem, na melhoria da vida terrena, através dos métodos da educação, inspirados na filosofia e na ciência". Anísio Teixeira acredita na possibilidade de uma vida digna e plena, por meio da democracia. Nada mais inspirador portanto que o encontro com Lobato, cujas aspirações democráticas e seu desejo de uma vida digna para o Brasil estão expressos em seus escritos inaugurais e de toda sua vida, como fica patente em cartas trocadas entre ambos. Lendo essas cartas, observando as ideias da nova pedagogia e a trajetória das obras de Lobato, não é difícil perceber que ambos comungam, captam e expressam, cada um a seu modo, o ideário de Dewey. O que não constitui nenhuma surpresa porque tais ideias são o corolário da concepção democrática de mundo fundada na psicologia, biologia e sociologia, as novas ciências que vêm revolucionar o pensamento social e fundamentar a Escola Nova. 
O conjunto das cartas entre ambos, na sua totalidade perfazem exatas quatro dezenas de cartas, sendo 23 de Anísio e 17 de Lobato (NUNES, 1986, p. 8). Ao seu conteúdo tivemos acesso por meio da Biblioteca Virtual Anísio Teixeira, onde parte delas está depositada e de artigo de Cassiano Nunes, que traz excertos reveladores. Das leituras constatou-se que a troca de ideias e a amizade de ambos era fecunda. Admiravam-se mutuamente e ambos falavam de seus projetos: uma nova pedagogia, uma nova literatura. Depreende-se das cartas que o conhecimento sobre a Escola Nova por parte de Lobato resumia-se ao que podia extrair das obras de Anísio, mas principalmente das conversas com ele, tanto que, quando Fernando de Azevedo lhe fornece uma cópia do Manifesto ${ }^{4}$, em carta a Teixeira, que Nunes assinala como escrita na década de 30 Lobato argumenta:

Comecei a ler o Manifesto. Comecei a não entender, a não ver ali o que desejava ver. Larguei-o, pus-me a pensar - quem sabe está em algum livro de Anísio o que não acho aqui - e lembrei-me dum livro sobre a educação progressiva que me mandaste e que se extraviou no caos que é a minha mesa. Pus-me a procura-lo. Achei-o. E cá estou, Anísio, depois de lidas algumas páginas apenas a procurar dar berros de entusiasmo por essa coisa maravilhosa que é a tua inteligência lapidada por Deweys e Kilpatricks! (NUNES, 1986, p. 26).

A menção no plural aos idealizadores da Escola Nova dão a medida de que Lobato vê neles um conjunto muito mais amplo a construir aquele movimento, inclusive, o próprio Anísio. Diz ele em seguida: "Eureka! Eureka! Você é o líder! Você é quem há de moldar o novo plano educacional brasileiro". Lobato tem sonhos civilizatórios e para ele "A "nossa educação" cairá como chuva de neve sobre o país, sem saber e sem querer saber onde os flocos irão pousar" (Ibid., p. 26).

Da amizade e admiração mútuas não se suspeita, constata-se, a julgar por outros excertos, cujo registro aqui é feito com o intuito de materializar e assim humanizar a relação entre ambos grandes intelectuais, e mais, oferecer uma pequena mostra das trocas intelectuais entre ambos como atestam cartas encontradas na Biblioteca Virtual Anísio Teixeira:

Estou lhe escrevendo do Queen Elizabeth, de viagem para New York. Pouco antes de deixar Paris, recebi sua carta e posso lhe dizer que você, mais uma vez, determinou a direção da minha vida. [...] Sua carta sacudiume como uma rajada de vento e resolvi ficar. [...] É espantoso que você em Buenos Aires veja a UNESCO melhor do que eu! [...] A sua carta, entretanto, fez-me reconsiderar tudo isto. Vou ficar mais algum tempo. Pensar é uma coisa, realizar um pensamento outra. [...] Escreva-me. Preciso de suas cartas e ainda mais preciso de vê-lo (TEIXEIRA, 1947 in CONVERSA ENTRE AMIGOS..., 1986).

Fui há dias ao drugstore ... e dei com uma nova edição da História da Filosofia por um dólar. Lembrei-me do que disseste do livro e comprei-o. E fiz mais: li-o, e com regalo e com assombro por não achar ressaibo de sectarismo no expositor. Poucas vezes se terá escrito sobre filósofos e filosofias com encanto de romancista bom, como o fez Durant. E lido Durant pus-me a ler outras coisas e parece que estou curado da obsessão wall-streeteana. [...] E fique certo, meu 
caro, que você diminuiu New York com a deserção. Deixou nossos domingos vazios e insípidos - e estragou museus e novidades. Se vou sozinho, sinto nostalgia dum companheiro; se vou acompanhado, arrependo-me. Comparo o companheiro que tive e acho muito vulgares e flat os que o acaso me depara. (LOBATO, 1930).

Acerca de um propósito pedagógico mais intencional de Lobato de colocar sua obra a serviço da nova pedagogia, o que se conseguiu apreender foi, no artigo de Nunes (1986, p. 27), uma carta sem data na qual Anísio dá notícia da recepção da obra Emília no País da Gramática, publicada em 1934, dizendo do alvoroço que causara ao grupo.

De todo modo, embora não se haja encontrado nenhum indicativo de intencionalidade explícita de Lobato em relação a se colocar dentro da escola nova como um partícipe, é possível captar aproximações entre a literatura infantil de Lobato e os fundamentos da Escola Nova que estão contidos em obra de John Dewey. A proposição que sustenta a teoria educacional desse pensador é a de que o processo educativo consiste na adequada interação entre a criança tal como ela é - um ser imaturo e não envolvido, de um lado, e o professor experiente e maduro que representa os fins, as ideias e os valores sociais, de outro lado. O fim da educação seria harmonizar a natureza da criança com o seu viver em sociedade, por meio de uma adequada interação desses elementos (DEWEY, 1965, p. 69).

Para Dewey, o mundo da criança é o seu aqui e agora, não tem futuro e nem passado mais amplo do que sua vivência familiar; de modo que o universo mais amplo da sociedade não cabe no seu universo restrito à infância. Nesse sentido, a escola deve ter como foco a vida presente, tal como ela se dá para o aluno.

A vida da criança é integral e unitária: é todo única [...]. A unidade de interesses pessoais e sociais que dirigem a sua vida mantém coesas todas as coisas que a ocupam. Para ela, aquilo que prende seu espírito constitui, no momento, todo o universo, que é assim, fluido e fugidio, desfazendo-se e refazendo-se com espantosa rapidez (DEWEY, 1965, p. 70).

De forma que é a criança que está em questão. Essa unidade e integralidade a tornam o centro em torno do qual devem se pautar as atividades do professor; sua singularidade é o universo em torno do qual a educação deve se realizar para que no futuro venha a ser um adulto pleno, realizado e feliz. A escola tradicional, todavia, ao colocar como centro do ensino aprendizagem, não o universo infantil mas o conhecimento livresco, desconsidera as diferenças que fazem único esse universo infantil e não o tomando em conta, induzem as crianças ao se verem de frente, prematuramente, com uma ordem lógica dos fatos que tornam o ensino enfadonho e aborrecido. Em consequência, a formulação de uma disciplina rígida, de castigos desnecessários, caso se adotasse uma pedagogia mais respeitosa às singularidades da infância. O pensamento de Dewey definirá uma pedagogia a partir das necessidades e da vontade do aluno, nela não cabendo a rígida disciplina adotada pela escola tradicional; seus instrumentos didáticos serão considerados ultrapassados e, por isso mesmo, inadequados para a nova pedagogia.

No caso da escola brasileira, registra-se um movimento a partir dessa nova pedagogia. Não se pretende fazer uma exposição de como ocorreu esse movimento em sua totalidade senão registrar a nova concepção de instrumentos didáticos, no caso, do livro e da leitura, que é o que interessa a esta investigação. A Escola Nova sobreleva a leitura e o livro como instrumentos educacionais por excelência e tem como defensor dessa ideia Fernando Azevedo. Em alguns capítulos da obra A Educação e seus Problemas (1953), o educador 
trava uma discussão acerca da diferença conceitual entre o livro didático tradicional, utilizado até então pelas escolas e os novos livros adequados à escola daquele momento. $\mathrm{O}$ capítulo ‘A renovação educacional e o livro' (pp. 191-194) constitui seu pronunciamento no encerramento da Semana do Livro em 1933, no qual aponta para aquele novo momento histórico da educação, alertando para o fato de que, se o livro didático - o livro texto sempre esteve presente na escola, no ensino tradicional ele assumia uma função despótica, absorvente e reguladora das atividades escolares infantis, guiando até mesmo o professor. "A criança escraviza-se ao 'texto' que guia o mestre, disposto e habituado antes a seguir as indicações metodológicas dos textos escolares... do que as sugestões dos alunos" (DEWEY, 1965, p. 191).

De acordo com os ideais da nova educação, o centro da gravidade se desloca do professor preso ao livro texto, para a criança e para o respeito a sua liberdade e espontaneidade. Azevedo defende com afinco, que o livro assuma uma nova função, deixando de ser o livro texto, único e diretivo até das atividades do professor, para ser o livro escolar, se transformando assim em um maravilhoso "instrumento de trabalho", multiplicando-se em cada matéria, para que o aluno possa manuseá-los e obter informações, recolher material de estudos e reflexão e "por simples prazer" (Ibid., p. 192).

Empolgado com os ventos liberais que varrem o cenário brasileiro, esse autor vai mais longe. Em "A nova função do livro escolar", discurso proferido por ocasião da inauguração da Biblioteca Escolar Fernando Azevedo em 1933, a educador defende a relevância que terão as bibliotecas a partir dessa nova significação do livro escolar.

É que, com a renovação das técnicas de ensino, que rejeita a rígida disciplina de livros padronizados, de leitura ou de texto, se alarga cada vez mais o campo de estudo, de investigação e de trabalho que oferecem as bibliotecas, onde o aluno, liberto do livro de texto, do "livro único", vai encontrar, acessível, para o seu benefício e prazer, uma variedade sempre renovada de livros suscetíveis de satisfazer à multiplicidade de seus interesses, de seu gostos, de suas aptidões e de suas necessidades (DEWEY, 1965, p. 195).

Com a ideia de uma escola cujo centro é a criança com suas necessidades e aspirações, e com livros voltados ao universo unitário da criança, a obra infantil conquista a escola. Aqui Lobato vai ganhar espaço, quando o livro irá adquirir essa nova função mais compatível com a ampliação de conhecimentos, para ser lido de forma prazerosa e voluntária.

Por ser um liberal afinado com as perspectivas progressistas de seu tempo, pela sua amizade com Anísio Teixeira e Fernando de Azevedo, Lobato conhece os preceitos da Escola Nova, dialoga com seus principais mentores, inaugura uma editora que possa escoar sua produção e, finalmente, decide criar uma nova fórmula para $A$ menina do Narizinho Arrebitado, mais adequada às necessidades de uma nova educação e que contribuísse para fazer avançar o projeto de um novo Brasil. Inicia, então, a confecção de uma obra, reunindo nela sua produção anterior. Nela busca, de forma lúdica, porém, ácida, inculcar nas crianças brasileiras um olhar lúcido e crítico aos problemas do país. Com esses elementos e nesse cenário educacional, o escritor constrói a nova versão de A Menina do Narizinho Arrebitado, com o título de Reinações de Narizinho, que está em vigor até hoje. É uma obra qualitativamente inédita porque Lobato reúne e organiza toda a sua produção anterior em 
torno de um eixo narrativo que é o Sítio do Pica-pau Amarelo, Em outubro de $1931^{15}$, escreve a Rangel, participando-lhe da sua ideia de unificar suas histórias infantis:

Tenho em composição um livro absolutamente original, Reinações de Narizinho - consolidação num volume grande dessas aventuras que tenho publicado por partes, com melhorias, aumentos $\mathrm{e}$ unificações num todo harmônico. (MONTEIRO LOBATO, s.d., p. 329 apud PARENTE, 2012, p. 30)

Em consonância com os princípios de uma educação democrática, ciente desde o sucesso do seu livro A Menina do Nariz Arrebitado, do desinteresse das crianças pela velha literatura que circulava nas escolas, vai finalmente, com Reinações de Narizinho, realizar a façanha de fundir o maravilhoso com situações cotidianas, no espaço ruralista brasileiro do sítio. Diz Bertolucci (2005, p. 79) "que as histórias lançadas anteriormente passam por profundas transformações e nesse processo de aperfeiçoamento constante que imprime à própria obra, o escritor vai encontrando a forma mais adequada de dar contas das situações que quer comunicar". Essa obra provoca um salto qualitativo não só na literatura de Lobato mas em toda a literatura dita infantil produzida anteriormente no país. Não envereda pelo caminho das moralidades e do nacionalismo apologético, não mapeia um falso Brasil, ao contrário, com recursos da oralidade, de neologismos, da re-significação de conceitos, de mitos e personagens, tudo dentro de uma nova espacialidade e temporalidade, Lobato, finalmente, opera a fusão entre a vivência do dia a dia das crianças com os elementos do maravilhoso ${ }^{6}$ que compõe a melhor literatura universal. Com esses recursos, obtém uma fórmula estética coesa, unitária, face a qual a criança consegue se reconhecer na sua integralidade. O universo do sítio, carregado de críticas e irreverências, especialmente por parte de Emília, é de fácil e prazerosa apreensão exatamente pela contradição que se instaura entre a realidade do país rico, vário, mas inexplorado e por isso problemático, de que o sítio representa um recorte, e o mundo da fantasia. Dessa fusão, obtém-se o melhor literatura infantil brasileira, numa linguagem acessível, sedutora e próxima ao universo infantil e ao mesmo tempo realista, na melhor expressão do modernismo literário no Brasil.

Ao se comparar as duas versões percebe-se que, na primeira, muito embora o título expressasse uma característica própria da personagem principal, que é uma criança do nariz arrebitado, o formato da obra ainda remetia muito vivamente aos contos do universo do maravilhoso, personagens e cenários - um reino, o das águas claras, um príncipe e todo seu séquito, no mesmo universo palaciano - que compunham os contos europeus clássicos, sobre príncipes e fadas. Esse era o modelo narrativo. Faz presença inclusive, a Carochinha, cujos contos extraídos da tradição oral europeia foram recuperados por Perrault e traduzidos em 1894, por Figueiredo Pimentel como Contos da Carochinha (MENDES, 2000, p. 139). É importante esse registro em função do caráter moralista desses contos, que marcaram a literatura infantil até o começo do século XX, lidos nas escolas como forma de imprimir valores morais da sociedade burguesa nas crianças. A mesma autora, inclusive, registra que o autor dedica a obra a uma mulher, frisando o caráter moralista dos contos, que ressaltam a importância da mulher na vida familiar, como já o fizera Perrault, há duzentos anos. Esse moralismo na literatura é uma das características que será combatida por Lobato.

Embora na primeira versão da obra o título seja A Menina do Narizinho Arrebitado, o foco é uma incursão ao Reino das Águas Claras, universo simbólico vivido em sonho pela personagem. Esse universo, no qual se desenvolvem as ações, nem de longe sugere qualquer 
aproximação com o mundo unitário da infância preconizado por Dewey. Ao contrário, é o universo clássico dos contos de fada, que sempre vem marcado pelo distanciamento temporal expresso no Era uma vez...

Já nas Reinações de Narizinho, o autor retoma a história da primeira versão. As aventuras passadas no Reino das Águas Claras abrem o livro, mas com as mudanças necessárias. A primeira mudança é no título, que sugere o lúdico, a infância, as brincadeiras, enfim, reinações. O foco agora não é mais um reino, mas um sítio no qual vive Dona Benta e sua neta Narizinho e as demais personagens. A narrativa da primeira versão, que possuía a estrutura dos contos maravilhosos, é colocado como parte de uma estrutura mais ampla, aproximativamente novelesca, embora não cumpra algumas das exigências estruturais da novela. Nesta, a opção do escritor por conferir ao narrador o papel de relatar episódios a partir de um determinado lugar fixo, de onde tudo vê e tudo sabe a respeito da matéria narrada, confere à mesma um grau muito acentuado de verossimilhança. A obra obedece a uma estrutura novelesca próxima de As mil e uma noites e do Decamerão, de Boccacio, nas quais uma personagem ou um conjunto delas são protagonistas das diferentes histórias que vão sendo narradas. É justamente essa estrutura que confere unidade à narrativa.

Na primeira versão, descrita em tom melancólico, mora uma triste velhinha de mais de 70 anos - numa casinha branca, lá muito longe. Esse distanciamento construído pela expressão "lá muito longe" é o que propicia a oportunidade para que Narizinho saia do real para entrar na fantasia. Qual é a fantasia? O Reino das Águas Claras. Esse reino compõe uma unidade, porém distanciada do real, a moda dos contos de fada. Ou seja, o real, o universo infantil é sem sabor. Por isso a fuga para o maravilhoso. E a narrativa segue até o final dentro desse universo de sonho, no ponto em que "lá na porteira" uma "tia velha de lenço amarrado na cabeça" chama por Narizinho, que desperta. Não passara de um sonho. Ou seja, o prazer, a fantasia não ocorrem no nível do real. Ora, em uma pedagogia em que se quer que a escola propicie prazer ao aluno, por meio da aproximação ao seu universo unitário, nada menos apropriado.

Que faz Lobato em Reinações de Narizinho? Modifica a estrutura narrativa situando a casinha branca em um espaço do real fictício e carregado de verossimilhanças: o Sítio do Pica-Pau Amarelo. Nesse, que é o ponto de partida e de chegada para as grandes aventuras da vida, vivem as personagens. Será esse o espaço no qual a fantasia e a realidade constituirão uma unidade. No qual as ações entre o "Era uma vez..." e o "Foram felizes para sempre" acontecem. Onde sonhar e viver fazem parte do mesmo processo. Onde o entrar e o sair da fantasia se obtém por meio de elementos do maravilhoso, os poderes do pó de pirilimpimpim, ou um simples fechar e abrir de olhos. Para conferir mais veracidade, Lobato traduz um diálogo entre Dona Benta e tia Nastácia:

Dona Benta, de fato, nunca dera crédito às histórias maravilhosas de Narizinho. Dizia sempre: "Isso são sonhos de crianças". Mas depois que a menina fez a boneca falar, Dona Benta ficou tão impressionada que disse para a boa negra: Isto é um prodígio tamanho que estou quase crendo que as outras coisas fantásticas que Narizinho nos contou não são simples sonho, como sempre pensei (LOBATO, s.d., p. 33).

No sítio, as ações e a própria atmosfera das narrativas respiram positividades. Dona Benta passa de feliz e bem contente da vida à mais feliz das avós. Na primeira versão tem mais de 70 anos. Na outra, mais de sessenta. Na primeira versão vivem, no nível do real, três 
criaturas: a avó, a neta e tia Nastácia. As demais personagens não compõem o cenário do real. Com exceção da boneca Emília, são todos do Reino das Águas Claras, naturalmente com um conjunto de seres do maravilhoso - um porco elevado a condição de marquês, um sabugo de milho que é visconde, uma boneca de pano e um burro que falam. O universo do maravilhoso não é recusado, mas passa ao plano da realidade do Sítio. Ou este passa ao plano do maravilhoso. Ocorre uma simbiose entre a fantasia e o real. É a ideia unitária de Dewey transposta à literatura. Até mesmo o Reino das Águas Claras, ganha uma nova dimensão, pois não é mais preciso sonhar para adentrá-lo. É pois uma fórmula de trazer até as crianças, dentro de um universo familiar bem conhecido por elas, a grande literatura universal. No Sítio desfilam desde Cinderela, Branca de Neve, até o Capitão Gancho, Peter Pã, o Barba Azul, o Gato Félix e etc. O conhecimento acontece estimulado pela sensibilidade e pela vivência infantil, bem como preconiza a escola nova. Dona Benta, a avó, vai narrando histórias na medida em que as personagens da literatura universal vão visitando o Sítio. Essa foi a fórmula encontrada por Lobato para aproximar a criança da literatura, de forma prazerosa, porque os alunos vão sendo sutilmente impelidos a entrar no sítio, conhecer as personagens e vivenciar suas aventuras.

Desse modo, é a criança que está em destaque. Ela é o centro em torno do qual deve se pautar a literatura. E porque, tanto no sítio, quanto fora dele, as ações são decididas e realizadas por crianças, as aventuras passam a ser um estímulo para que os pequenos leitores, no futuro, sejam criaturas operantes, com iniciativa própria, plenas, realizadas e felizes porque se percebem livres e donas de seu próprio destino, porque os objetivos da educação surgem do livre desenvolvimento das próprias experiências, estimuladas pelas experiências da turma do sítio "O objetivo ou recompensa do aprendizado é a capacidade de desenvolvimento constante" (DEWEY, 1965, p. 73). E, mais importante ainda, enquanto na primeira versão as ações se concentram todas em Narizinho, sempre conduzida pelo príncipe, em Reinações... elas são desenvolvidas pelo grupo, reforçando mais esse postulado da escola nova. Dentro ou fora do sítio, as personagens infantis estão juntas e inclusive às vezes, carregam dona Benta, a avó, que se deixa levar por eles.

Esse movimento que parte do real fictício e se funde com o maravilhoso é coincidente com um outro postulado de Dewey qual seja, a ideia de que a vida é um processo que implica situações em constante movimento de renovação e, por isso, a educação deve partir de experiências concretas que coloquem a vida em movimento e propiciem renovações. A experiência, como parte das relações humanas levariam as crianças a interações transformadoras.

No plano humano esse agir e reagir ganha sua mais larga amplitude, chegando não só à escolha, à preferência, à seleção, possíveis no plano puramente biológico, como ainda à reflexão, ao conhecimento e à reconstrução da experiência (DEWEY, 1985, p. 113 apud SANTANA, 2011, p. 32).

Por isso, a vida no sítio é tão agitada. No esforço de articular a experiência com a obra literária, Lobato transforma o sítio numa espécie de laboratório de onde se extrai o substrato para as aventuras das personagens; das histórias narradas por Dona Benta extrai o mote para as constantes viagens da turminha do sítio e também estimula o contato com a literatura clássica. 
A viagem é o tempo no qual o sujeito, a nação ou a obra de arte se realizam graças à experiência que fazem do mundo. A experiência efetivada - o oposto da "caceteação da escola" - consiste em que houve uma reunião, uma vivência, uma unidade a ser enfrentada (CARDOSO, 2006, p. 98).

A tessitura das personagens também é sugestiva de uma mudança de foco na literatura de Lobato, que entra em consonância com os ditames da Escola Nova. Nas Reinações... Dona Benta não é mais apenas uma avó. Ela detém o saber erudito. É a mestra, a que conta histórias, a que lê. Todavia, suas ações são sempre pautadas no interesse das crianças. Essa proposição é importante para compreendermos o fundamento que pode ter estimulado Lobato a interferir na linguagem da obra aqui analisada. Dona Benta difunde ideias e palavras selecionadas do ideário brasileiro, mas sempre procurando romper com o ufanismo elogioso e fora de propósito e com o distanciamento da linguagem, própria não só da literatura clássica universal como da literatura que andava pelas escolas brasileiras e que tanto incomodava Lobato. ${ }^{7}$ Todavia, essa personagem denota grande conhecimento, traz à baila importantes personagens da literatura universal e não deixa de incorporar palavras do vocabulário erudito nas histórias que conta aos pequenos, mas sempre com o cuidado de esclarecer o seu significado, de fazer com que compreendam o que estão ouvindo ou lendo, o que sugere que Lobato não repudia a cultura e a literatura universais, mas deseja fazer com que ela chegue às crianças brasileiras numa linguagem acessível. A propósito dos conhecimentos de Dona Benta, esclarece o autor:

Dona Benta era uma senhora de muita leitura; além de ter uma biblioteca de várias centenas de volumes, ainda recebia, dum livreiro da capital, as novidades mais interessantes do momento. Uma tarde o correio trouxe-lhe a Child's History of the World, de V. M. Hillyer, diretor da Calvert School, de Baltimore (LOBATO, 19--, p. 239 apud SANTANA, 2011, p. 68).

Outra personagem de destaque, a mais conhecida e decantada até os dias de hoje, é Emília. Legítima representante do que a Escola Nova apregoa: uma voz retumbante, uma crítica audaciosa e honesta, iniciativa e apresentação de soluções ousadas e corajosas, para os problemas. Entusiasmada com tudo o que fosse novo e diferente, apresentava, não obstante, a ingenuidade e inocência própria das crianças.

Emília, diz com autoridade, Coelho (1987, p. 100), é indiscutivelmente a personagem mais importante de Lobato porque "é a única que vive em tensão dialética com os outros". A autora registra o caráter positivo de sua incessante mobilidade, o seu fazer coisas, sua curiosidade aberta para tudo ou a franqueza rude. Talvez, por isso, a crítica a tenha consagrado como alter-ego de Lobato.

Tia Nastácia é figura de proa, porque responde pelos saberes populares, folclóricos, tão caros a Lobato e aos modernistas das Letras. Detém o domínio de uma culinária tipicamente brasileira, na nomenclatura, no sabor e no cheiro. $\mathrm{O}$ autor recorre a essa personagem todas as vezes que deseja aproximar os ensinamentos daquilo que considera mais genuinamente brasileiro, como por exemplo, quando quer sair do universo dos mitos europeus para valorizar a nossa própria mitologia. Ou quando quer estabelecer determinada cultura culinária, como o famoso "bolinho de chuva" da Nastácia, prato favorito da criançada do sítio.

Operando rupturas com a linguagem passadiça dos livros da literatura universal e brasileira e dando voz a uma personagem representativa por excelência das feições do povo brasileiro, como é o caso de Tia Nastácia, o autor res-significa, também, os conceitos de 
pedagogia e moralidade presentes nas literaturas que circulavam pelas escolas. Ao invés da obediência e submissão, a rebeldia; ao invés do aprendizado formal, o aprendizado oriundo das experiências do dia a dia.

No sítio, a aprendizagem das crianças se dá aos moldes da escola nova, no contato informal propiciado pelo sítio que, de certo modo, substitui o espaço formal e rígido da escola. As crianças - Narizinho e Pedrinho - e a boneca Emília aprendem de forma espontânea, em contato com os muitos livros de uma biblioteca do próprio sítio, na qual abunda a grande e boa literatura clássica, que vai sendo lida para as crianças, nos "serões de dona Benta", porém, com linguagem coloquial, infantil e totalmente abrasileirada.

O sítio é, assim, a representação por excelência da nova pedagogia. Um espaço no qual as crianças podem ver em exercício a sua autonomia, em cujas histórias aprendem de maneira prazerosa a viver e a realizar experiências as mais significativas. Onde aprendem a viver em grupo e a trocar ideias, por meio das personagens infantis, sob os olhares cuidadosos de Dona Benta e tia Nastácia.

\section{Considerações finais}

Nada na revisão da literatura indica com certeza sequer a proximidade, quanto mais a intencionalidade nas transformações operadas por Lobato na obra estudada em relação à Escola Nova. E mesmo ao observar os contatos do autor com Anísio Teixeira, de quem era mais próximo, não se consegue entrever qualquer intencionalidade ou compromisso de obediência aos ditames da Escola Nova. A literatura de Lobato parece desenvolver-se mais no entusiasmo das mudanças, das novidades, do que em qualquer teoria. $\mathrm{O}$ fato é que a Escola Nova é um movimento de enorme amplitude e profundidade porque surge no bojo de mudanças estruturais da própria sociedade, como expressão dessas mudanças. Ninguém, então passa ao largo delas, especialmente, um homem da têmpera de Lobato.

Neste artigo, apenas foram formuladas as aproximações mais plausíveis aos postulados da nova pedagogia, quais sejam, o exercício democrático, a busca da autonomia por meio da experiência e, principalmente, uma metodologia de trabalho que caminhasse rumo à formação do homem na sua integralidade. Buscou-se na matriz do próprio Dewey os elementos que permitissem responder às indagações formuladas neste texto. As modificações sofridas pela primeira versão da obra revelaram uma profunda compreensão do fenômeno literário por Lobato. Ele conseguiu com Reinações de Narizinho, inaugurar a Literatura Infantil Brasileira que, até então, não houvera conseguido desprender-se do colonialismo das letras europeias.

Buscou-se demonstrar por meio da própria literatura, a ruptura operada por Lobato, trazendo à baila textos literários autores renomados, utilizados anteriormente a ele nas escolas brasileiras e demonstrar o divisor de águas representado pela obra aqui estudada. Nem de longe este artigo oportuniza registrar a amplitude e a relevância da obra lobatiana em seu conjunto, em função do recorte operado, até porque a obra desse grande autor vai muito além do que a crítica literária, já abundante, conseguiu registrar, em todas as suas nuances.

Todavia, acredita-se que a relevância deste artigo reside em evidenciar alguns elementos significativos de aproximação da obra de Lobato às transformações ocorridas na educação por meio do movimento da Escola Nova. Esse modelo pedagógico fez parte de um dos momentos mais importantes da história brasileira no século XX: os decênios que conduziram o país ao seu alinhamento com as forças capitalistas, tirando-o, finalmente, da condição material e cultural de colônia portuguesa. Esse apogeu, essa culminância de forças produtivas em desenvolvimento trouxe à cena os mais expressivos intelectuais que 
comandaram as mudanças pedagógicas necessárias ao Brasil daquele momento. Lobato não fez o que fez sozinho, embora o tempo todo tentasse preservar sua individualidade, como se pôde perceber por seus depoimentos e pelo registro dos biógrafos. Ele foi impulsionado por forças sociais muito poderosas, que captou graças à sua educação apurada, à sua condição material de vida e à sua história individual pregressa. Isso tira Monteiro Lobato da condição de gênio, restaurando sua humanidade preciosa ao entendimento de que o mundo avança pela mão dos homens e não pela do gênio. E confirma um dos postulados da Escola Nova: o de que as grandes mudanças são realizadas coletivamente.

Este artigo, mais do que uma contribuição aos estudos sobre esse grande autor, representa uma humilde homenagem de quem bebeu durante toda a infância nas suas pródigas páginas e cuja herança ainda embala os sonhos e estimula o caminhar.

\section{Referências}

AZEVEDO, Carmen Lucia de; CAMARGOS, Márcia; SACCHETTA, Vladimir. Monteiro Lobato: furacão na Botocúndia. São Paulo: SENAC. 1998.

AZEVEDO, Fernando de. A educação e seus problemas. São Paulo: Melhoramentos, 1948.

BARBOSA, Francisco de Assis. Monteiro Lobato e o direito de sonhar. Posfácio ao fac símile da $1^{\mathrm{a}}$ edição de A menina do narizinho arrebitado. São Paulo, 1982.

BERTOLUCCI, Denise Maria de Paiva. A composição do livro Reinações de Narizinho, de Monteiro Lobato: consciência de construção literária e aprimoramento da linguagem narrativa. Tese de doutorado. UNESP - Assis, 2005.

BIGNOTO, Cilza. Personagens infantis da obra para adultos e da obra para crianças de Monteiro Lobato: convergências e divergências. Tese de doutorado. UNICAMP, 1999.

CAMARGO, L. A imagem na obra lobatiana. In: LAJOLO, M., CECANTINI, J. L. (Org.) Monteiro Lobato, Livro a livro: obra infantil. São Paulo: Editora UNESP: Imprensa Oficial do Estado de São Paulo, 2008.

DEWEY, John. Vida e educação. São Paulo: Melhoramentos, 1965.

CARDOSO, Maria Angélica. A literatura de formação e os conteúdos escolares nos escritos de Monteiro Lobato: apontamentos para uma prática pedagógica. Roteiro, Joaçaba, v. 31, n. 1-2, p. 89-122, jan./dez. 2006.

COELHO, Nelly Novaes. Literatura infantil: história, teoria e análise. 4. ed. São Paulo: Quíron,1987.

LA FONTAINE. Fábulas. Tomo I. São Paulo. Gráfica e Editora Edigraf, s/d.

LAJOLO, Marisa; ZILBERMAN, Regina. Literatura infantil brasileira - história e histórias. 2. ed. São Paulo, Editora Ática, 1985.

MARTHA, Alice Áurea Penteado. Monteiro Lobato e a fábula vestida à nacional, Mimesis, Bauru, v. 20, n. 2, 71-81, 1999. 
MENDES, Mariza. B. T. Em busca dos contos perdidos: o significado das funções femininas nos contos de Perrault. São Paulo: Editora UNESP/Imprensa Oficial do Estado de São Paulo, 2.000.

MONTEIRO LOBATO. Reinações de Narizinho. São Paulo: Círculo do Livro, s/d.

MONTEIRO LOBATO. Fábulas. São Paulo: Editora Brasiliense, 2002.

NUNES, Cassiano. Monteiro Lobato e Anísio Teixeira: o sonho da educação no Brasil. São Paulo: Biblioteca Infantil Monteiro Lobato. 1986.

NETTO, Coelho; BILAC, Olavo. A pátria brasileira. Rio de Janeiro: Francisco Alves, 1940. $27^{a}$ edição. Disponível em: <www.unicamp.br/iel/memoria/ Ensaios/LiteraturaInfantil >.

OLAVO BILAC, Poesias infantis, 1904. Disponível em: 〈http://www.brasiliana.usp.br>.

PARENTE, Luciane. A linguagem desliteraturizada de Monteiro Lobato em Reinações de Narizinho. Dissertação de Mestrado. UNESP - Campus de Rio Claro, 2012.

ROLIM, Z. Livro das crianças. Boston: C. F. Hammett, 1897. Disponível em: <www.unicamp.br/iel/memoria $>$.

SALEM, Nazira. História da literatura infantil. São Paulo: Mestre Jou, 1970.

SANTANA, J. A. Lopes. Monteiro Lobato: ação e literatura no movimento da escola nova no Brasil. Monografia. UEMS, 2011.

SOUZA, Ana A. Arguelho de. Literatura infantil na escola: a leitura em sala de aula. Campinas: Editora Autores Associados, 2010.

SOUZA, Ana A. Arguelho de. A linguagem brasileira de Monteiro Lobato. Revista Philologus. Suplemento: Anais da V JNLFLP. Rio de Janeiro: CiFEFiL, Rio de Janeiro, 2012.

TAMBARA, Elomar; ARRIADA, Eduardo. Civismo e Educação na Primeira República João Simões Lopes Neto. História da Educação, ASPHE/FaE/UFPel, Pelotas, v. 13, n. 27 p. 279-292, Jan/Abr 2009. Disponível em: http//fae.ufpel.edu.br/asphe

TEIXEIRA, Anísio. Carta a Monteiro Lobato, a bordo do Queen Elizabeth, 29 jan. 1947. In: Conversa entre amigos: correspondência escolhida entre Anísio Teixeira e Monteiro Lobato. Salvador: Fundação Cultural do Estado da Bahia, Rio de Janeiro: Fundação Getúlio Vargas/CPDOC, 1986. pp. 104-107. Disponível em: <http://www.bvanisioteixeira.ufba.br/correspond.htm>. Acesso: 01 mar 2017.

VECHIA, A.; LORENZ, K. M. (orgs.). Programa de ensino da escola secundária brasileira: 1850-1951. Curitiba: Ed. do Autor, 1998.

ZILBERMAN Regina. A literatura infantil na escola. 11. ed., São Paulo: Global, 2003. 


\section{Notas}

1 Este artigo é parte de Pesquisa interinstitucional, intitulada: "A Organização do Trabalho Didático na Perspectiva de Educadores da Escola Nova (1930-1970)", que conta com apoio financeiro do CNPq.

${ }^{2}$ Professora aposentada da UEMS. Doutora em Letras; mestre em Educação. anaarguelho @ yahoo.com.br.

3 Maria Zalina Rolim Xavier (1869-1961) foi uma expressiva poeta e educadora brasileira Sua influência na educação foi João Köpke. Nasceu em Botucatu (SP), em 20 de julho de 1869 e exerceu o magistério como professora alfabetizadora. Entre 1896 e 1897, exerceu o cargo de vice inspetora, do Jardim da Infância anexo à Escola Normal Caetano de Campos, em São Paulo. Escreveu para diversas revistas femininas e jornais como A Mensageira, O Itapetininga, Correio Paulistano e A Província de São Paulo. Deixou três obras literárias: 1893 - O coração; 1897 - Livro das Crianças; 1903 - Livro da saudade (organizado nessa data para publicação póstuma).

${ }^{4}$ Supõe-se que seja o Manifesto dos Pioneiros da Escola Nova.

${ }^{5}$ Embora uma das datas mais apregoadas pelos pesquisadores para a publicação de Reinações... seja o ano de 1934, Bertollucci, em sua tese de doutorado traz fortes evidencias de que a obra teria sido publicada em 1931 inclusive indicando que a segunda edição teria ocorrido em 1933 e nenhuma em 1934. E mais, afirma que o título da edição de 1931 seria As reinações..., só passando a circular sem o artigo definido na edição de 1947. Afirma a autora que a polêmica acerca da data de publicação da primeira edição se deve à confusão com as datas de publicação individual das histórias que compõe a obra. p. 70-74.

${ }^{6} \mathrm{O}$ maravilhoso é a categoria indicativa dos elementos que tornam a literatura mágica e encantatória, conferindo-lhes potencialidade para transcender o real por carregar em si uma carga de poder transformador.

${ }^{7}$ Registra-se que Lobato possuía uma verdadeira ojeriza pelo culto brasileiro aos mitos estrangeiros. Implicava com os gnomos e anões de jardim; substituiu o fabulário europeu e mitos germânicos como os nibelungos, por mitos genuinamente nacionais, além de ter desencadeado a pesquisa nacional sobre a figura lendária e tipicamente brasileira do saci-pererê, já mencionada na introdução. O leão e o tigre dos bestiários deram lugar ao macaco, ao bicho preguiça, ao papagaio e, desse modo foi reciclando e abrasileirando os elementos do folclore e da tradição popular europeia.

Recebido: Abril/2017.

Aprovado: Junho/2017. 